\title{
Modeling 5 years of subglacial lake activity in the MacAyeal Ice Stream (Antarctica) catchment through assimilation of ICESat laser altimetry
}

\author{
Sasha P. CARTER, ${ }^{1}$ Helen A. FRICKER, ${ }^{1}$ Donald D. BLANKENSHIP, ${ }^{2}$ \\ Jesse V. JOHNSON, ${ }^{3}$ William H. LIPSCOMB, ${ }^{4}$ Stephen F. PRICE, ${ }^{4}$ Duncan A. YOUNG ${ }^{2}$ \\ ${ }^{1}$ Institute of Geophysics and Planetary Physics, Scripps Institution of Oceanography, University of California, San Diego, \\ 9500 Gilman Drive, La Jolla, California 92093-0225, USA \\ E-mail: spcarter@ucsd.edu \\ ${ }^{2}$ Institute for Geophysics (UTIG), John A. and Katherine G. Jackson School of Geosciences, University of Texas at Austin, \\ J.J. Pickle Research Campus, Bldg 196, 10100 Burnet Road (R2200), Austin, Texas 78758-4445, USA \\ ${ }^{3}$ Department of Computer Science, University of Montana, Social Science Building, Room 417, \\ Missoula, Montana 59812-5256, USA \\ ${ }^{4}$ Los Alamos National Laboratory, Los Alamos, New Mexico 87545, USA
}

\begin{abstract}
Subglacial lakes beneath Antarctica's fast-moving ice streams are known to undergo $\sim 1 \mathbf{k m}^{3}$ volume changes on annual timescales. Focusing on the MacAyeal Ice Stream (MaclS) lake system, we create a simple model for the response of subglacial water distribution to lake discharge events through assimilation of lake volume changes estimated from Ice, Cloud and land Elevation Satellite (ICESat) laser altimetry. We construct a steady-state water transport model in which known subglacial lakes are treated as either sinks or sources depending on the ICESat-derived filling or draining rates. The modeled volume change rates of five large subglacial lakes in the downstream portion of MacIS are shown to be consistent with observed filling rates if the dynamics of all upstream lakes are considered. However, the variable filling rate of the northernmost lake suggests the presence of an undetected lake of similar size upstream. Overall, we show that, for this fast-flowing ice stream, most subglacial lakes receive $>\mathbf{9 0} \%$ of their water from distant distributed sources throughout the catchment, and we confirm that water is transported from regions of net basal melt to regions of net basal freezing. Our study provides a geophysically based means of validating subglacial water models in Antarctica and is a potential way to parameterize subglacial lake discharge events in large-scale ice-sheet models where adequate data are available.
\end{abstract}

\section{INTRODUCTION}

Recent observations acquired through multiple independent techniques, including interferometric synthetic aperture radar (InSAR; Gray and others, 2005), satellite radar and laser altimetry (Wingham and others, 2006a; Fricker and other, 2007) and GPS (Tulaczyk and others, 2000), have shown that subglacial lakes undergo repeated volume fluctuations on annual to decadal timescales. It has been suggested that these lakes, which underlie most of Antarctica's fast-flowing ice streams (Fricker and others, 2007, 2010; Smith and others, 2009), influence ice flow by reducing basal traction and altering the availability of water for basal lubrication downstream (Bell, 2008). In the fastflowing regions of Byrd Glacier, a speed-up event of $10 \%$ lasting 14 months was correlated with the flooding of two subglacial lakes involving $1.7 \mathrm{~km}^{3}$ of water (Stearns and others, 2008), showing the potential for such events to impact the ice sheet's mass balance. Data for monitoring lakes are limited; detailed observation of subglacial activity is currently limited to the operational period of NASA's Ice, Cloud and Land Elevation Satellite (ICESat) from 2003 to 2009 (Fricker and others, 2010). Additional observations of surface change have come from InSAR (Gray and others, 2005) and satellite radar altimetry (Wingham and others, 2006a), but the former has limited temporal sampling in the Antarctic and the latter lacks the spatial resolution to detect events in fastflowing ice streams (Fricker and others, 2010). Unfortunately,
ICESat operations ceased in December 2009, and the resulting time series is only just long enough to observe the cyclical nature of subglacial floods and is insufficient to examine these cycles in detail (Fricker and Scambos, 2009).

Initial attempts to compare observed volume changes in subglacial lakes to estimated water budgets have generally compared the sum of all observed volume changes in a given catchment with the modeled discharge for that catchment (e.g. Llubes and others, 2006; Smith and others, 2009). Smith and others (2009) showed that observed volume changes for lakes on the Siple Coast of West Antarctica approach the total water budget of the region, but they did not deal with the behavior of individual lakes because they lacked accurate information on hydrologic flow paths. Studies that have focused on individual lakes for which flow paths are reasonably well determined (e.g. Whillans Ice Stream (Fricker and others, 2007); Adventure Trench (Carter and others, 2009a; Fricker and others, 2010)) have been limited by a lack of information on the total meltwater budget. Most current ice-sheet models do not incorporate subglacial water transport, and instead simply tune the basal traction parameter to reproduce fast-moving ice. The few models that do include subglacial water transport (e.g. Johnson and Fastook, 2002) generally assume that it is in steady or quasi-steady state, ignoring episodic lake drainage. To understand how subglacial lake dynamics might impact basal traction beneath ice streams and outlet glaciers, it is necessary to 


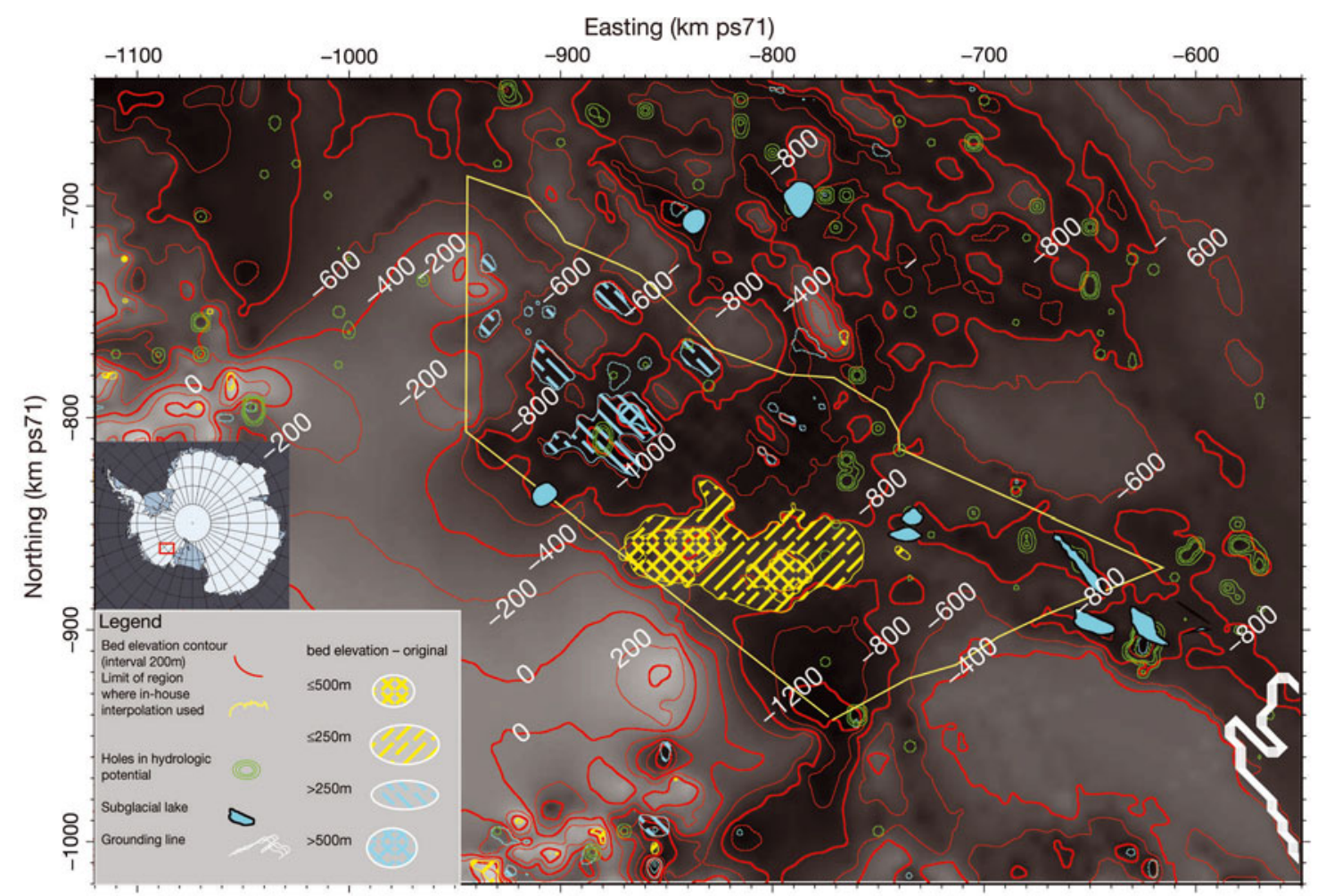

$-1200-1100-1000-900-800-700-600-500-400-300-200-100 \quad 00100 \quad 200 \quad 300 \quad 400 \quad 500 \quad 600 \quad 700 \quad 800 \quad 900 \quad 1000 \quad 1100 \quad 1200$

Fig. 1. Bedrock topography, and regions where our interpolation scheme replaces BEDMAP PLUS topography. This region is defined in part by the availability of ice thickness measurements and how much they differ from the published interpolation. Green contours denote locations where enclosed basins in the hydrologic potential are present. Hatching indicates areas where bedrock DEM from this study differs from BEDMAP Plus DEM by $>250 \mathrm{~m}$.

consider an entire drainage basin and all of its known subglacial lakes. If the temporal distribution of water in this system varies substantially from steady state on annual to decadal timescales, this might explain some of the difference between the modeled steady-state water distribution and the estimated basal traction (Le Brocq and others, 2009). Furthermore, if subglacial floods comprise a large part of the water budget, then the long-term availability of water for basal lubrication may differ from that assumed by steadystate distributed models, especially if these floods evolve into flow conduits as inferred by Carter and others (2009a).

In this paper, we focus on MacAyeal Ice Stream (MaclS) which, based on the models of Le Brocq and others (2009), has the least ambiguous hydrologic catchment area of the six Siple Coast ice streams and contains at least ten known lakes (Smith and others, 2009; Fricker and others, 2010; Fig. 1). Our study formulates a model of the subglacial hydrology for MaclS, using satellite-based measurements of subglacial lake activity. Other inputs are digital elevation models (DEMs) for the ice surface and bedrock topography, and a published model for basal melt. Using this model we assess the significance of subglacial lake floods in the context of the greater subglacial hydrologic system.

\section{STUDY REGION AND SCOPE}

MaclS has an active subglacial water system containing eight subglacial lakes, which we number from the grounding line upstream as Mac1, Mac2, etc. (Fig. 2). The activity of the lakes in the system was reported by Smith and others
(2009) using ICESat laser altimetry; the downstream portion was studied in detail by Fricker and others (2010) who assimilated ICESat with other remote-sensing data to obtain more accurate estimates of lake volume change. A 2005-06 seismic survey also pointed to subglacial water activity elsewhere on MaclS (Winberry and others, 2009). We treat MaclS as a closed system surrounded by no-flow boundaries with adjacent ice streams (Le Brocq and others, 2009). A preliminary map of water drainage at a coarse $(5 \mathrm{~km})$ resolution has a dendritic pattern, with Mac1-Mac5 occupying areas of high water flux (Fricker and others, 2010). In contrast, the water systems for other ice streams appear anastomosing (i.e. many flows reconnect after branching) and contain major bifurcations, such as the diversion of water from upper Kamb Ice Stream to Whillans and Bindschadler Ice Streams (Anandakrishnan and Alley, 1997; Johnson and Fastook, 2002; Le Brocq and others, 2009). These reconnections and diversions make it difficult to couple upstream and downstream processes.

Our study does not address the physical mechanisms of flood initiation and termination (e.g. Evatt and others, 2006; Fowler, 2009), nor does it try to identify a particular flow mechanism (i.e. focused conduits versus distributed sheets/ cavities; e.g. Flowers and Clarke, 2002; Creyts and Schoof, 2009; Schoof, 2010). Also, we do not directly address the relationship between the water system and the flow of overlying ice. We do, however, explore the feasibility of using existing data to test models that include these mechanisms. First, we show how improved analysis of the input data, in spite of uncertainties, can be used to 


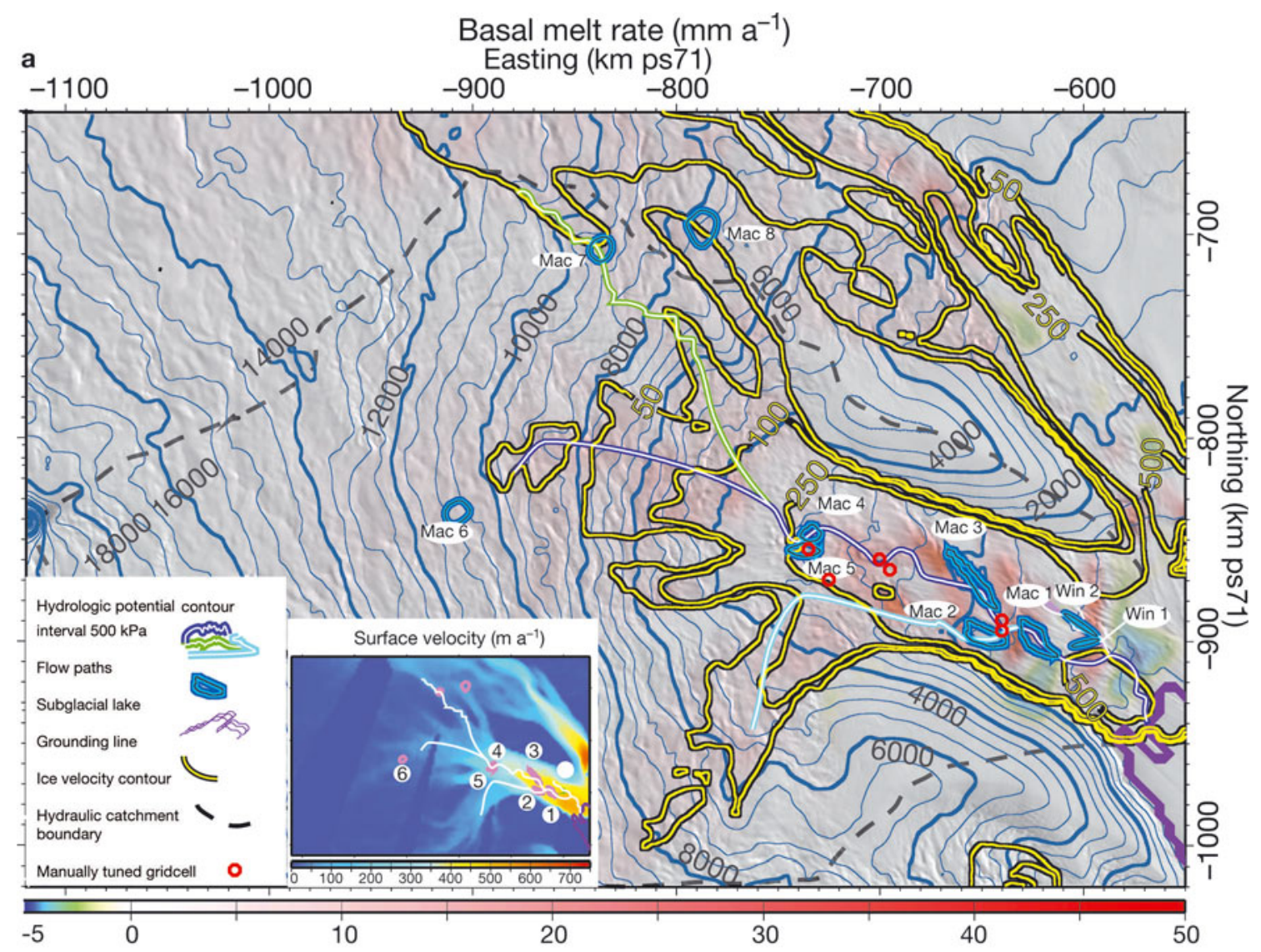

b

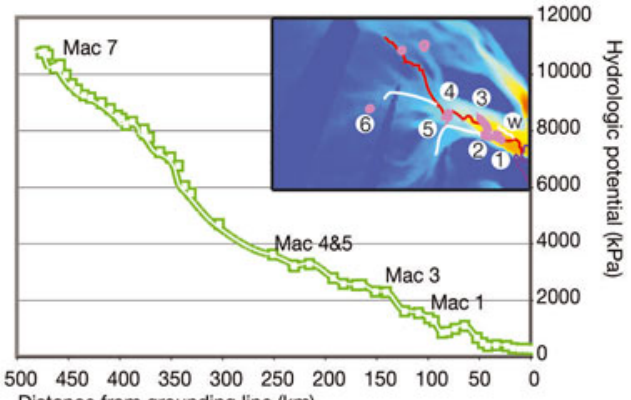

C

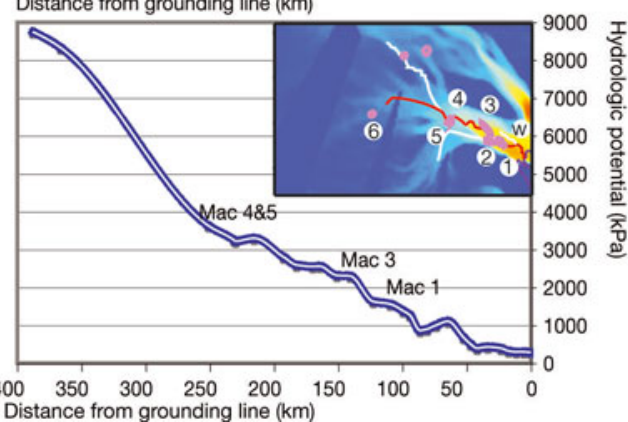

d

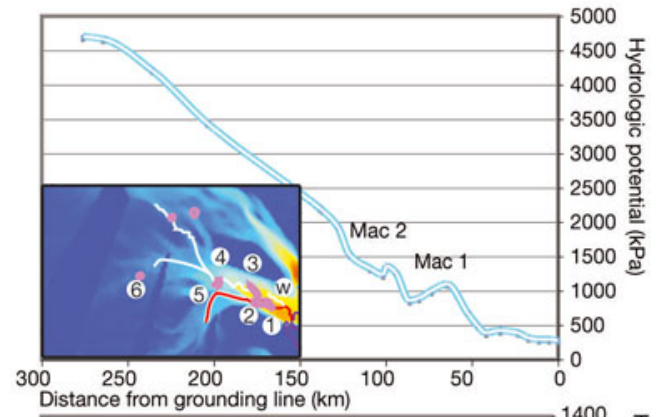

e

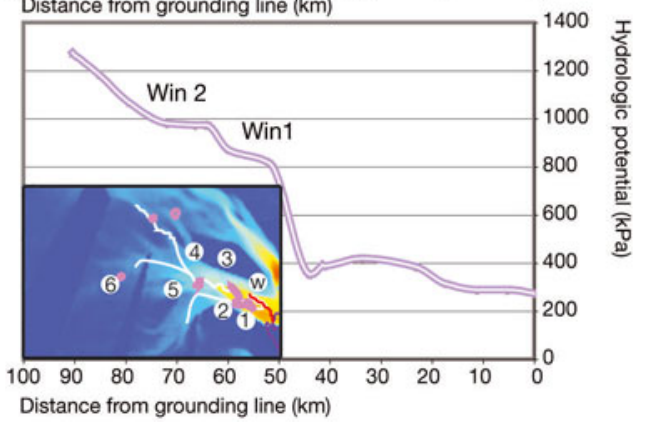

Fig. 2. (a) Basal melt rate with contours of hydrologic potential (blue) and ice surface velocity (yellow; Joughin and others, 2004; contours at 50, 100, 250 and $500 \mathrm{~m} \mathrm{a}^{-1}$ ). (b-e) Hydrologic potential as determined from correlated local minima along RES flight-lines, with location maps inserted. Hydrologic potential decreases monotonically except at subglacial lakes for all flow paths as determined through methods described in Section 4.1.2.

parameterize, tune and validate a simple model of basal water distribution. We then use the data to evaluate several long-held hypotheses (described in the next section) about the transport and distribution of basal water. We acknowledge that there is room for further data analysis and more realistic models. We aim to show, however, that even a simple model can explain recent geophysical observations related to subglacial water flow.
The first question we address is: Do subglacial lakes beneath ice streams and outlet glaciers obtain most of their water from local sources or from distant sources? Many subglacial lakes are located in or immediately downstream of areas of high basal melt associated with geothermal anomalies (e.g. volcanoes) or ice-dynamical anomalies (e.g. 'sticky spots' - regions of enhanced basal friction (Blankenship and others, 1993, 2001; Bell and others, 2007; Siegert 
and others, 2007; Carter, 2009a; Smith and others, 2009; Fricker and others, 2010; Sergienko and Hulbe, 2011); Fig. 2). It is unclear, however, whether these zones of enhanced melting are the primary water source for lakes or whether the lakes receive much of their water from diffuse sources throughout the catchment. Also, it has been hypothesized that water transport from areas of high melt to areas of net basal accretion downstream is responsible for basal lubrication where the ice would otherwise freeze to the bed (Parizek and others, 2002). In this study, the lakes farthest downstream are adjacent to areas where basal accretion is predicted (Joughin and others, 2004; Fig. 2). If the observed volume change for these lakes is consistent with meltwater sourced from the entire basin, then we have more observations to support this hypothesis.

The second question we address is: What fraction of water in the subglacial system is subject to temporary storage in subglacial lakes? If this fraction is large, then we can conclude that subglacial lakes play a major role in the dynamic distribution of basal water. Additionally, if subglacial lakes temporarily impound a large enough fraction of the water passing through them, then observations of lakefilling and -draining events can be used to validate more complex models of sub-ice-sheet hydrology (e.g. Flowers and Clarke, 2002; Parizek and others, 2002; Schoof, 2010). Furthermore, if the flow mechanism for subglacial floods is qualitatively different from that which is assumed to transport subglacial water in a steady-state system, this could have implications for the relationship between basal sliding and water supplied from upstream (Kamb, 1987; Schoof, 2010).

\section{DATA AND DATA PREPARATION}

Our model requires three inputs: hydrologic potential, basal melt rate and a time series of volume-change estimates for each subglacial lake in the system. Hydrologic potential is estimated from ice surface elevations derived from ICESat and Moderate Resolution Imaging Spectroradiometer (MODIS) data (Fig. 3) and ice thicknesses derived using data from a combination of radio-echo sounding (RES) and seismic surveys spanning 1957-2005 (Bentley and Ostenso, 1961; Drewry, 1975; Blankenship and others, 2001). Basal melt rates are obtained from the results of a published temperature model of the area (Joughin and others, 2004). The time series of lake volumes come from ICESat and MODIS (Smith and others, 2009; Fricker and others, 2010). Below we describe in detail the generation of the model inputs from these datasets.

\subsection{Hydrologic potential}

Hydrologic potential is determined by the water elevation and pressure, and exerts a first-order control on the subglacial water distribution: water flows from high to low potential. In Antarctica the subglacial water pressure is usually assumed to be equal to the overburden or lithostatic pressure (Vogel and Tulaczyk, 2006; Le Brocq and others, 2009). Although the overburden pressure can exceed the actual water pressure by up to $200 \mathrm{kPa}$ in fast-flowing regions (Engelhardt and Kamb, 1997), the assumption that water pressure is equal to overburden is sufficient for our study.

Hydrologic potential, $\theta_{\mathrm{h}}$, was calculated as

$$
\theta_{\mathrm{h}}=g\left(\rho_{\mathrm{w}} Z_{\mathrm{srf}}-h_{\mathrm{i}}\left(\rho_{\mathrm{w}}-\rho_{\mathrm{i}}\right)\right),
$$

where $z_{\text {srf }}$ is the ice surface elevation, $\rho_{\mathrm{i}}$ and $\rho_{\mathrm{w}}$ are the densities of ice and fresh water, respectively, and $h_{\mathrm{i}}$ is the ice thickness. Therefore the two datasets needed to construct hydrologic potential over a region are the ice surface elevation and the ice thickness. Below we describe how we obtained these two datasets for MaclS.

\subsubsection{Ice surface elevation}

We estimated ice surface elevation from a $250 \mathrm{~m}$ resolution DEM derived from ICESat laser altimetry, acquired between 2003 and 2004 and enhanced with MODIS photoclinometry (Haran and Scambos, 2007). The nominal accuracy of this DEM is $1-2 \mathrm{~m}$; however, at the $5 \mathrm{~km}$ resolution of our model grid this error is substantially lower.

Estimation of the hydrologic potential requires generating DEMs that optimize the use of data in well-sampled regions while minimizing artifacts in regions where ice thickness data are sparse. The DEMs used to generate hydrologic potential surfaces in this study averaged multiple measurements for gridcells where such measurements existed and interpolated for cells where no measurements existed. Although the dependence of the hydrologic gradient on the ice surface gradient is about ten times greater than the dependence on the bed gradient, the latter can locally exceed the former by an even larger factor (Shreve, 1972). Thus, although the regional flow of subglacial water is controlled primarily by the ice surface gradient, bedrock topography could exert an important control on the local water flow. It is possible that features smaller than the $5 \mathrm{~km}$ grid resolution could control local water routing and in some places change the regional water routing, as demonstrated in recent models (Wright and others, 2008).

\subsubsection{Ice thickness}

We estimated ice thickness using a combination of RES and seismic surveys spanning 1957-2005. Along-track resolution varied from $3 \mathrm{~km}$ for the earlier Scott Polar Research Institute/ US National Science Foundation/Technical University of Denmark (henceforth SPRI) surveys (Drewry, 1975) to $<10 \mathrm{~m}$ for the most recent University of Texas Institute for Geophysics Thwaites Catchment survey (UTIG-THW) (Holt and others, 2006). Most of the data from the remaining UTIG Support Office for Aerogeophysical Research (UTIG-SOAR) surveys had an along-track spacing of $\sim 30 \mathrm{~m}$ (Blankenship and others, 2001). In areas where there were no RES data we used measurements from seismic traverses associated with the first International Geophysical Year (Bentley and Ostenso, 1961; Bentley and Chang, 1971). Where neither RES nor seismic data were available, we relied on interpolation strategies described by Lythe and others (2001) for the BEDMAP compilation and on subsequent improvements from the BEDMAP Plus database (Pritchard and others, 2009). In merging a variety of data sources, we considered both the uncertainty at the time of measurement and the possibility that ice thickness has subsequently changed. The uncertainty in ice thickness may be as large as $50 \mathrm{~m}$ in areas of steep bedrock topography, but is much lower for the lowrelief areas under most of MaclS (Table 1). To estimate decadal changes in ice thickness we used published results from two independent satellite techniques: satellite radar altimetry (Wingham and others 2006b) and mass flux measurements (Rignot and others, 2008), which unfortunately extended back only to 1992 . Both techniques suggested that the maximum local rate of surface change was $\sim 0.1 \mathrm{~m} \mathrm{a}^{-1}$ for 1992-2008. Satellite laser altimetry 


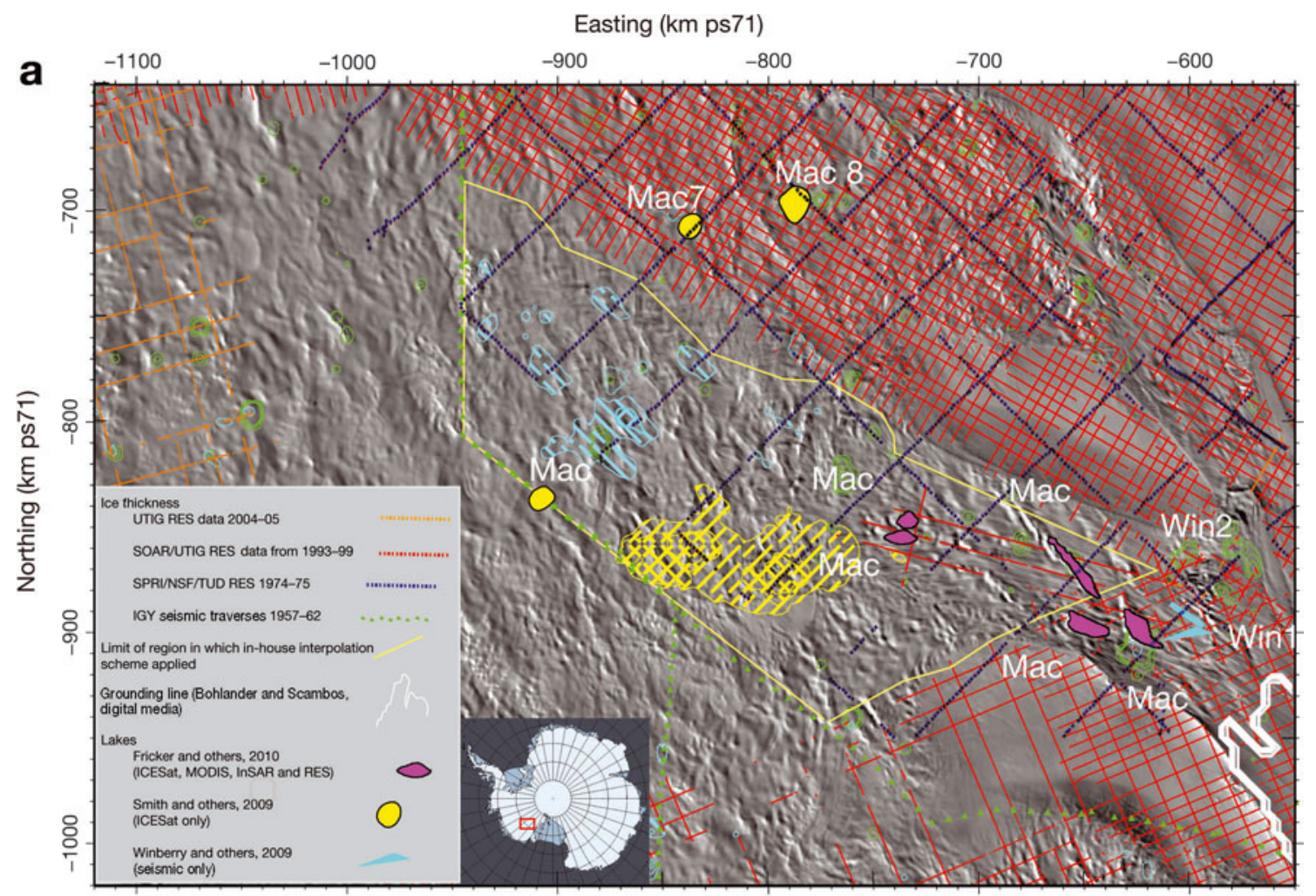

b

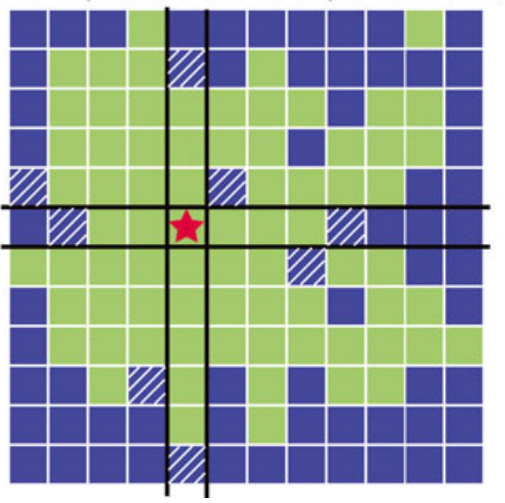

Fig. 3. (a) Map showing locations and types of data used for this study. The surface elevation is derived from a photoclinometric DEM that uses MODIS shading to interpolate elevation points from ICESat surface altimetry (Haran and Scambos, 2007; T. Haran and others, http://nsidc.org/ data/nsidc-0280.html). Surface velocities are obtained from an InSAR analysis by Joughin and others (2002). Lake locations and shoreline dimensions come from three separate studies. Ice thickness comes from multiple RES and seismic campaigns, most of which were performed between 1993 and 2005, with earlier campaigns used primarily to fill in blank areas. Grounding line is from J. Bohlander and T. Scambos, nsidc.org/data/atlas/news/antarctic_coastlines.html. (b) A schematic diagram showing how we perform bedrock interpolation. Cells with satisfactory values are blue. Cells with unsatisfactory values are green. A star marks the cell of interest. Black lines border cells in the same row or column as the cell of interest. White hash lines indicate cells used for interpolation; the basis for selecting these cells is given in Section 4.1.1.

(Pritchard and others, 2009) confirms this magnitude for 2003-08. This may introduce an error of up to $1 \mathrm{~m}$ in ice thickness for the faster-flowing portions of MaclS and up to $5 \mathrm{~m}$ for the interior. While all these errors sum up to a total of $60 \mathrm{~m}$ of ice thickness, this value is multiplied by $g\left(1-\rho_{\mathrm{l}} / \rho_{\mathrm{w}}\right)$ such that when it is added to the uncertainties from surface elevation we get a maximum error $\pm 60 \mathrm{kPa}$, with the largest contribution from ice thickness errors in regions of steep bedrock topography.

Comparison of ice thickness data from BEDMAP Plus with those from recent RES campaigns revealed that they contain errors of $>500 \mathrm{~m}$. Thus it was not possible to seamlessly blend the higher-resolution line data with the original interpolation for the central part of our study area (Fig. 1). To remedy this, we have used the misfit between measurements and the DEM to define an area in which to perform interpolation. Our hybrid algorithm combined the best features of bilinear and inverse-distance-weighting interpolation. Given the nonuniform distribution of ice thickness measurements, a simple inverse-distance weighting risks averaging too many values from a small region. Our algorithm identified eight nearby gridcells for which the ice thickness was based on a measurement. Two of these were in the same row, one on each side of the cell in question, and two others were in the same column, again with one on each side. The four remaining cells are the nearest cells with a satisfactory bed elevation in each of the quadrants formed by two vectors along the row and column of the cell in question (Fig. 3b). We used the inverse-distance-weighted average bed elevation from each of these eight cells to determine the bed elevation for a given cell. The resulting interpolated bed topography was then continuous with the 
Table 1. Data sources used

\begin{tabular}{|c|c|c|c|c|c|c|}
\hline Common name & $\begin{array}{c}\text { Date } \\
\text { collected }\end{array}$ & $\begin{array}{l}\text { Measurement } \\
\text { used for }\end{array}$ & To calculate & Error & $\begin{array}{c}\text { Impact of } \\
\text { error on final } \\
\text { calculation }\end{array}$ & Source \\
\hline $\begin{array}{l}\text { ICESat + MODIS } \\
\text { DEM }\end{array}$ & 2003 & Surface elevation & Hydrologic potential & $1 \mathrm{~m}$ & $1 \mathrm{~m}$ & Haran and Scambos (2007) \\
\hline $\begin{array}{l}\text { ICESat + MODIS } \\
\text { lake volume change }\end{array}$ & 2003-09 & $\begin{array}{c}\text { Surface elevation } \\
\text { change }\end{array}$ & Lake volume change & $1 \mathrm{~m}$ & $1 \mathrm{~m}$ & Fricker and others (2010) \\
\hline UTIG/SOAR & 1992-99 & Ice thickness & Hydrologic potential & $\begin{array}{l}11 \mathrm{~m} \text { in ice streams, up to } \\
86 \mathrm{~m} \text { in mountainous areas }\end{array}$ & & $\begin{array}{l}\text { Blankenship and others } \\
\qquad(2001)\end{array}$ \\
\hline THW & 2004-05 & Ice thickness & Hydrologic potential & Mean $8 \mathrm{~m}, \mathrm{RMS} 47 \mathrm{~m}$ & $\sim 2 \mathrm{~m}$ & Holt and others (2006) \\
\hline SPRI & $1971-75$ & Ice thickness & Hydrologic potential & $\begin{array}{c}50 \mathrm{~m} \text { thickness, } \\
1-3 \mathrm{~km} \text { positioning }\end{array}$ & $\sim 5 \mathrm{~m}$ & Drewry (1975) \\
\hline Seis & $1956-57$ & Ice thickness & Hydrologic potential & $40 \mathrm{~m}$ & $\sim 4 \mathrm{~m}$ & $\begin{array}{c}\text { Bentley and Ostenso (1961); } \\
\text { Bentley and Chang (1971) }\end{array}$ \\
\hline
\end{tabular}

well-measured topography, allowing us to further parameterize subglacial lakes and channels.

\subsection{Basal melt rate}

Our model assumes that all water enters the system as basal melt. We used the basal melt map of Joughin and others (2004), which showed that MaclS is unique among Siple Coast ice streams in that much of the melt occurs in the fastflowing downstream region (Fig. 2). This is due in part to the presence of large 'sticky spots' (MacAyeal and others, 1995), which convert gravitational potential energy into frictional melting. Fricker and others (2010) suggested that the high basal traction at these sticky spots would provide water from shear heating of the overlying ice, and that the contrast in basal traction would form a surface depression with consequent lowering of the hydrologic potential downstream of the sticky spot, resulting in the observed subglacial lake distribution. More detailed modeling by Sergienko and Hulbe (2011) has shown that localized areas of enhanced basal traction will create local minima in the downstream hydrologic potential where water will collect. Whether or not basal melt from these sticky spots is sufficient to explain observed lake volume changes is one of the questions addressed in this paper. For our error estimates we used the published value for basin-wide melt of $\pm 10 \%$ (Joughin and others, 2004).

There were two limitations in our model that result from (1) differences between the modern DEMs used in our study and the BEDMAP DEM used by Joughin and others (2004) and (2) the assumption that the melt rate was constant over the study period. Recent high-resolution DEMs for surface and bed elevation have revealed greater topographic detail than the BEDMAP DEM; differences are up to $500 \mathrm{~m}$ at some grid nodes (Fig. 1). The resulting differences in surface slope and thickness, however, appeared to average out over the basin and thus affected the actual spatial distribution of basal melt, but not the total volume of meltwater. Given that rates of lake-volume change integrate meltwater generated over spatial scales of ten ice thicknesses or greater (Joughin and others 2004), we considered these modeled melt rates to be sufficient for our study.

The assumption of constant melt rate over the study period may not be valid since changes in the melt rate could result from the passage of water along the interface (Creyts and Clarke, 2010), and water flowing up adverse bed slopes may require more heat than is available from turbulent heating and thus freeze out in places. Also, variations in the thickness of the water layer will influence its ability to conduct basal heat to the overlying ice. Simulating these processes, however, would have required a more complex water model, introducing additional uncertainty. Additionally, work by Carter and others (2009a) on a flood in Adventure Subglacial Trench showed that, for the low hydraulic gradients in much of the Antarctic ice sheet, the fraction of water gained and lost to hydrodynamic melting and freezing accounts for $<1 \%$ of the total water budget.

\subsection{Lake locations and volume-change estimates}

We used the locations of eight ICESat-detected lakes (Mac1Mac8; Smith and others, 2009; Fricker and others, 2010). We used estimates of volume changes from two published ICESat studies: for Mac1-Mac5, we used the estimates reported by Fricker and others (2010), which incorporated MODIS image data and had a maximum error of $\pm 20 \%$; for Mac6-Mac8 we also used estimates from Smith and others (2009). All ICESat time series were limited to the epochs of the ICESat acquisition campaigns, which were every 3-4 months. Additionally, there are two downstream lakes which were inferred through seismic monitoring of a subglacial flood in 2005 (Win1 and Win2 in Fig. 2; Winberry and others, 2009). Although there are no ICESat time series available over these lakes, we will show that their locations were useful for validating and evaluating our model.

In assuming that water is stored only in known lakes, we neglected potential storage elsewhere in the subglacial hydrologic system. Some models suggest that water can be stored in the subglacial till (Tulaczyk and others, 2000) and within the water sheet itself (Creyts and Schoof, 2009). Although these phenomena have been observed in boreholes (Engelhardt and Kamb, 1997), neither is currently observable on the spatial scale of the MaclS catchment. This assumption, like others, kept the model simple and testable against current observations.

\section{METHODS}

\subsection{Subglacial lakes and predicted flow paths}

To incorporate the effects of sub-gridscale topographic features on water routing and distribution, we designed an algorithm to follow the most prominent drainages, borrowing from an established Geographic Information System 


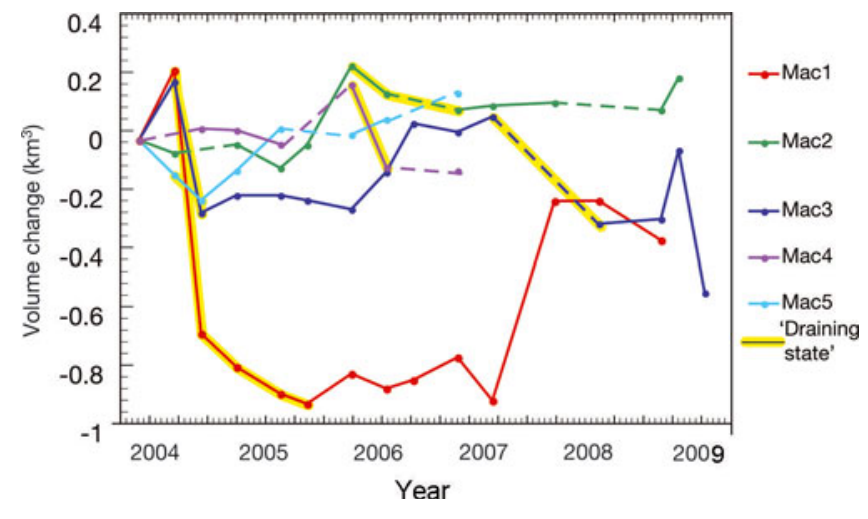

Fig. 4. Volume change over time for lakes Mac1-Mac5 adapted from Fricker and others (2010; reprinted with permission). We have highlighted portions of the plot that correspond to lake drainage events for which the volume loss is $>3 \mathrm{~m}^{3} \mathrm{~s}^{-1}$. We also neglect short events that may be artifacts of sampling errors, such as the drainage of Mac1 between November 2006 and March 2007.

(GIS) technique of stream etching into DEMs (Saunders, 2000). We used the 'law of $V^{\prime} s^{\prime}$ (Dupain-Triel, 1791) to identify a proto-drainage. We then determined the intersection between this proto-drainage and ground tracks of the RES ice thickness data. We used the position and head of the nearest local minimum in the hydrologic potential along the flight-line as a point in the drain path (Fig. 2). We interpolated the hydrologic potential, the $x$ and $y$ position of the intersections of the drainage and flight-line, the bedrock elevation, the ice thickness and the surface elevation along this path using a piecewise cubic hermitic polynomial to preserve monotonicity between data points. The hydrologic potential for all gridcells containing points of any drain path was then set to the mean of those points. If two drain paths were within two gridcells of one another but did not intersect, we altered the bed topography in some locations to prevent leaking and to better incorporate small observed barriers in the hydrologic potential, as determined by the original RES data. Figure 2 shows all places where this tuning is done.

Despite these improvements, the resulting hydrologic potential surface still contained many enclosed basins or 'holes'. Johnson and Fastook (2002) reported similar results and tried to associate these basins with subglacial lakes, a number of which were later confirmed by geophysical data (Siegert and others, 2005; Bell and others, 2007; Carter and others, 2007). For this study we worked only with lakes confirmed by previous geophysical studies. We differentially adjusted the hydrologic potential by raising the bed elevation of all holes, including those associated with known lakes, until there was a monotonically decreasing path in the hydrologic potential from every cell in the domain to the grounding line. Using this final version of the hydrologic potential, we parameterized the filling and draining of lakes in our flow model, as discussed next.

\subsection{The flow model and subglacial lakes}

For all gridcells lying outside a filling subglacial lake we prescribed water fluxes as

$$
Q_{\text {out }}=Q_{\text {in }}+m \Delta x \Delta y,
$$

where $Q_{\text {in }}$ and $Q_{\text {out }}$ are the incoming and outgoing water flux, $m$ is the basal melt rate (negative if water is freezing to the base) and $\Delta x$ and $\Delta y$ are the horizontal dimensions. Flux was distributed among the eight neighboring cells using the D8 routing algorithm (Quinn and others, 1998); cells with higher hydrologic potential received no flux, while cells with lower hydrologic potential received a fraction of the outflow, proportional to the local slope of the hydrologic potential surface:

$$
Q_{\mathrm{i}}=Q_{\text {total }} \frac{\left(\mathrm{d} h / \mathrm{d} s_{\mathrm{i}}\right)}{\sum_{n=1}^{k}\left(\mathrm{~d} h / \mathrm{d} s_{\mathrm{n}}\right)},
$$

with $k$ being the number of adjacent cells with lower hydrologic potentials, and $s$ the distance to the adjacent cell $\left(\Delta x, \Delta y\right.$ or $\left.\sqrt{\Delta x^{2}+\Delta y^{2}}\right)$. Le Brocq and others (2006) explored variants of this routing scheme.

\subsection{Lakes as sinks and sources}

We aimed to determine whether the estimated regional basal melt rate (Joughin and others, 2004) and the observed filling and draining of subglacial lakes were sufficient to explain the observed behavior of lakes downstream. In essence, we used the ICESat-derived time series of lake-drainage events to simply parameterize lake-drainage events and used the ICESat-derived time series of lake-filling events to validate the transport and melt model. We do not presume to know the exact mechanism by which subglacial floods are initiated; hypotheses for possible mechanisms are described elsewhere (Evatt and Fowler, 2007; Carter and others, 2009a; Fowler, 2009). Our simple model did not account for details related to channel geometry and water-pressure evolution and its impact on sliding. Nonetheless, if a simple model can show consistency among estimates for basal melt, observed lake volume changes and ice-surface and ice-bed topography, it may be possible to use observations of lake volume change to test more complex models. Also, this simple model served to validate hypotheses relating to the source regions for the subglacial lakes of MaclS.

For simplicity, we focused on the five lakes undergoing the largest volume changes in the catchment, Mac1-Mac5. We considered Mac6-Mac8 only for the purpose of quantifying discharge variability over time. The procedure was as follows: Any gridcell lying within the boundaries of a subglacial lake could be in one of two states: filling or draining. We considered a lake to be draining if and only if the volume change during a given interval was negative with a magnitude greater than $3 \mathrm{~m}^{3} \mathrm{~s}^{-1}$. We excluded events during which the apparent volume loss might be due to ICESat sampling issues, such as for Mac1 between November 2006 and March 2007. If the drainage condition was not met, or if there was no volume change during the interval, then we assumed that the lake was filling (Fig. 4). For filling lakes, water entering the lake perimeter increased the lake volume and did not leave the gridcell. For a draining lake, we allowed incoming water to pass through. We accounted for the downstream transfer of water following a lake drainage by dividing the volume change by the time interval and gridcell size and treating the result as a source for the gridcells immediately downstream.

In addition to a model run involving ICESat-observed filling and draining events, we also performed two control experiments to test the locations of the observed lakes with respect to modeled discharge and determine how their distribution might influence water availability downstream: one with no lakes, the other with all lakes filling. The 'lake- 

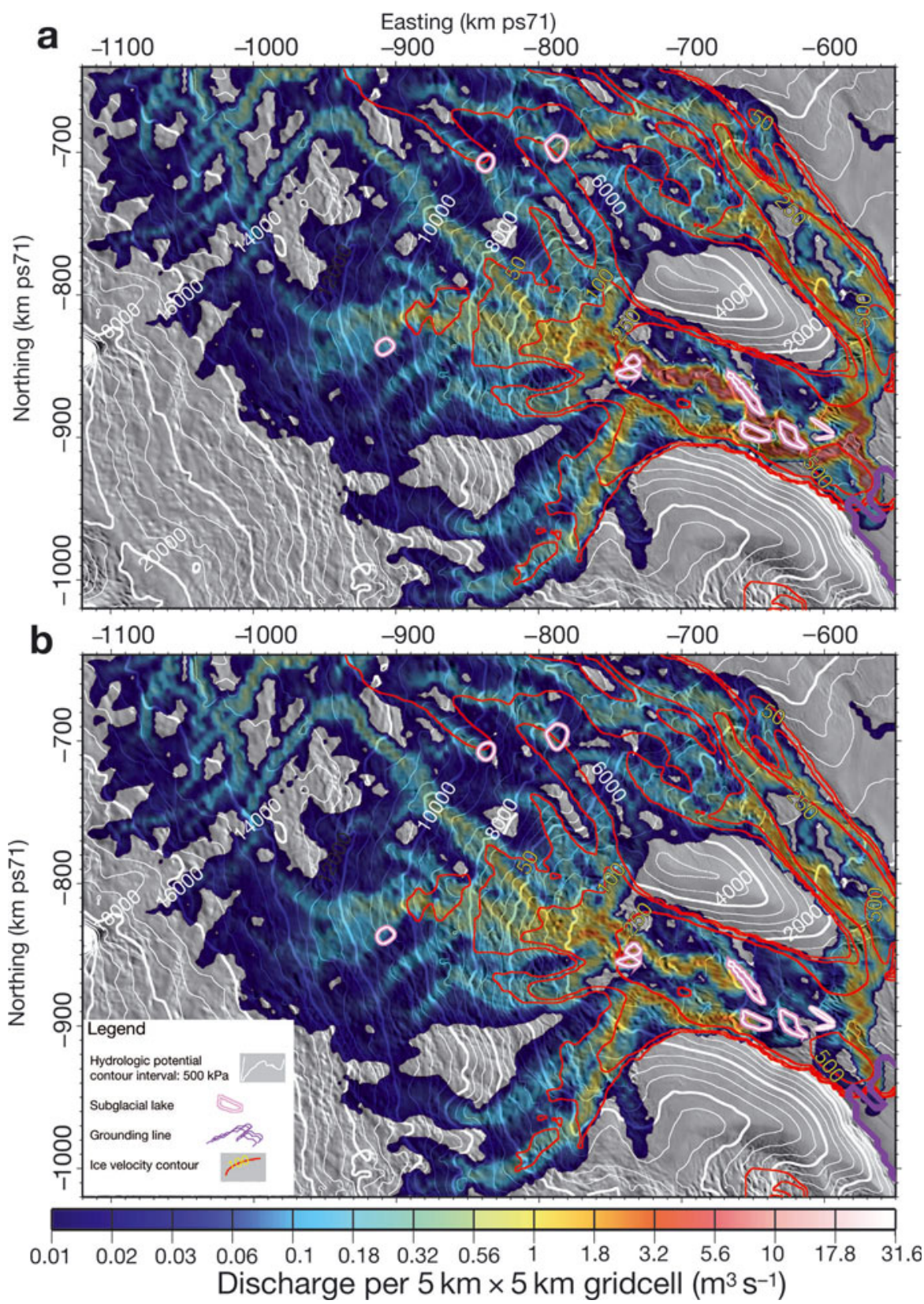

Fig. 5. Steady-state water flux with (a) lake-free run and (b) all-filling run. Note logarithmic color scale.

free' run was similar to the steady-state basal water model of Le Brocq and others (2009), except that it used more detailed bedrock topography and a simplified version of the routing algorithm. This run had a steady water distribution for a given melt rate and hydrologic potential, and the only sink was the Ross Sea. In the 'all-filling' run, we treated all lakes as sinks, both to see the areas where lakes will limit water availability and to test whether the observed filling rates can be reproduced entirely by meltwater from local sources (i.e. geothermal or frictional heating anomalies).

\section{RESULTS}

\subsection{Flow paths identify subglacial lakes as hydrologic potential basins}

An analysis of the RES line data indicated that there is a unique path of steepest descent on the hydrologic potential surface between every known subglacial lake in the study area and the grounding line. The monotonicity of this path was broken only at known subglacial lakes (Fig. 2). Given that our calculation of hydrologic potential neglected effective pressure and the observed surface elevation change over subglacial lakes (Fricker and others, 2010), we expected some enclosed depressions along the flowlines as they crossed subglacial lakes. There were no other departures from monotonicity along any flow paths. Johnson and Fastook (2002), who dealt exclusively with geometry from gridded datasets, identified many enclosed basins in the hydrologic potential that were later found to correlate with subglacial lakes. Our examination of the original RES line data provided strong support for the hole-filling algorithms of Johnson and Fastook (2002) and Le Brocq and others (2009).

\subsection{Control runs (lake-free and all-filling)}

Our lake-free model (Fig. 5a) differs from the models of Johnson and Fastook (2002) and Le Brocq and others (2009), primarily because we used different DEMs for the surface and 

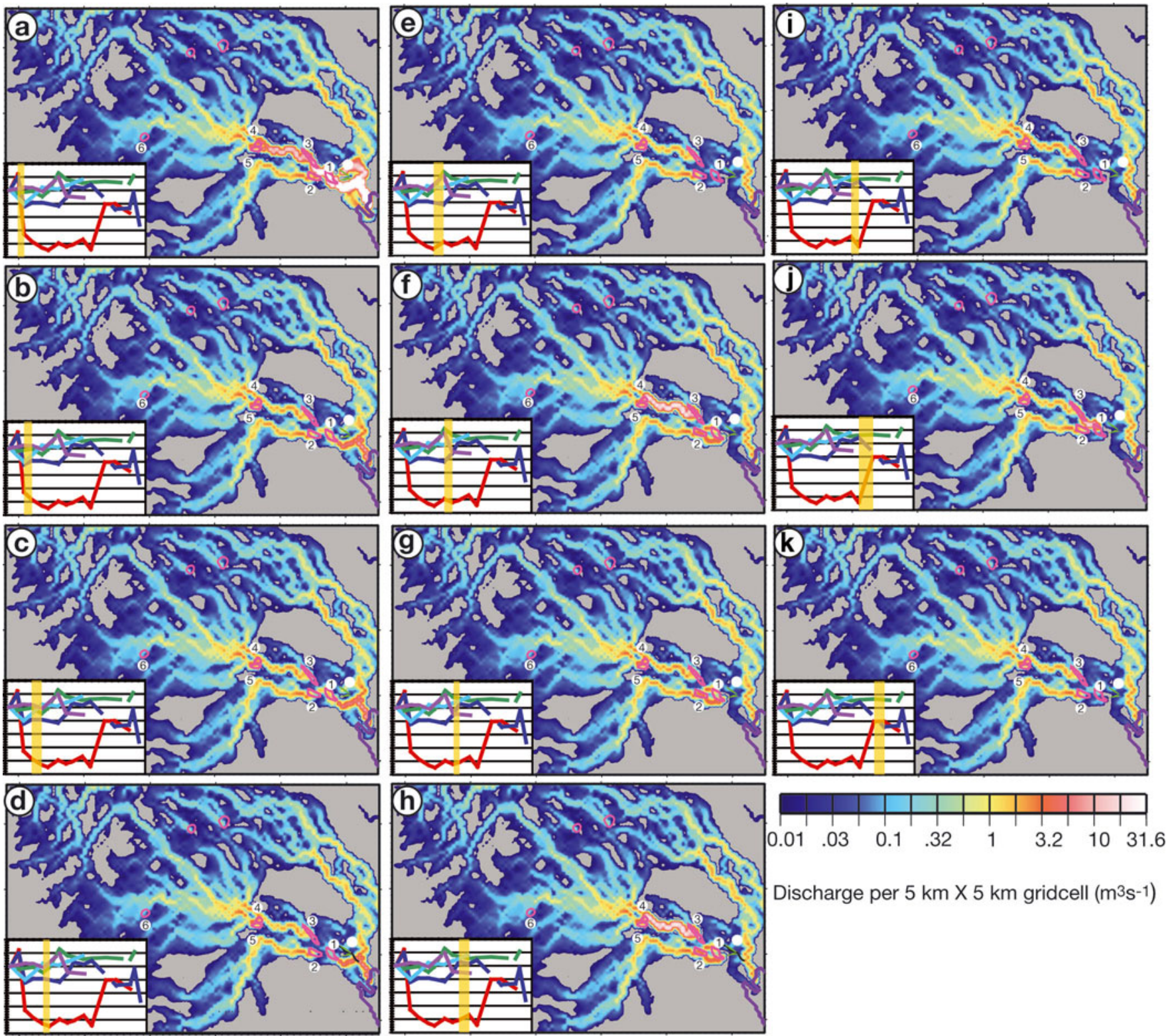

Discharge per $5 \mathrm{~km} \times 5 \mathrm{~km}$ gridcell $\left(\mathrm{m}^{3} \mathrm{~s}^{-1}\right)$

Fig. 6. Maps of modeled evolution of water distribution over time, forced with the lake volume-change time-series data from Fricker and others (2010) with time intervals selected to coincide with ICESat campaigns (line colors in inserts same as Fig. 4): (a) March-June 2004 (b) June-October 2004, (c) October 2004-March 2005, (d) March-June 2005, (e) June-November 2005, (f) November 2005-March 2006, (g) March-June 2006, (h) June-November 2006, (i) November 2006-March 2007, (j) March-October 2007 and (k) October 2007-March 2008. Note different color scale from previous figure.

elevation topography. This results in a stronger correlation between subglacial water distribution and the location of known subglacial lakes. The all-filling run showed a strong correlation between an abrupt increase in along-flow discharge and the presence of subglacial lakes. The meeting of several tributaries upstream of Mac4 and Mac5 appears responsible for their existence. In contrast, as pointed out by Fricker and others (2010), Mac1-3 are all close to regions of high basal melting provided by increased friction at sticky spots. All but one of the lakes occupied areas with a high steady discharge; the exception was Mac6 which lost water throughout the ICESat mission. If it filled, it may have done so at a rate below that detectable by ICESat. Thus our observed lake distribution was qualitatively consistent with the measured topography and inferred melt rate: lakes exist at hydropotential lows in areas of high basal water flux. These lakes have a large impact on the availability of water to downstream locations, despite their small spatial extent. This impact was clear in our all-filling run, in which water was nearly absent for tens of km downstream of all lakes (Fig. 5b).

\subsection{Flow evolution with time}

The time-lapse plots of modeled water distribution from March 2004 to March 2008 showed an early period of high discharge (March-June 2004; Fig. 6a). Water draining from Mac5 passes through Mac4 into Mac3, subsequently arriving at Mac1 (Fig. 6). The ICESat temporal sampling is insufficient to determine the exact timing of the draining/filling of the three lakes, except for Mac5, which appears to have started to drain before Mac3 and Mac1. During this period there was relatively more water supplied to the bed between Mac3, Mac4 and Mac5 (Fig. 6a). If the steady flow from Mac1 was real (i.e. not an artifact of our lake-volume averaging algorithm or surface change associated with 
dynamic effects (Sergienko and others, 2007)), then the water supplied by this event appears to have been enough to keep the bed downstream of Mac1 well lubricated for nearly 9 months after the end of discharge from other lakes (Fig. 6b-d). From June to November 2005, much of the bed below Mac1 had only local water supply (Fig. 6e). As our model did not consider changes in transmissivity or in storage outside lakes, we cannot assess whether other mechanisms may have lubricated the bed during this period. Water stored in subglacial sediments, however, is likely to help maintain lubrication, releasing water during dry periods and retaining it during subglacial floods (Tulaczyk and others, 2000). From November 2005 until March 2006, the regions between Mac2 and Mac1 and between Mac4 and Mac3 both had water influx following discharge from Mac2 and Mac4, respectively (Fig. 6f). The flood wave from Mac4 can then be seen passing from Mac3 to Mac1 between March 2007 and October 2007 (Fig. 6g-h). In all runs, almost all water in the catchment appears to have passed through Mac1.

\subsection{Discharge variability over time}

In the fastest-flowing regions of MaclS, where surface velocity exceeds $250 \mathrm{~m} \mathrm{a}^{-1}$, the range in modeled discharge values exceeded the steady-state discharge by an order of magnitude (Fig. 7). In some areas, such as downstream of Mac4 and Mac5, the water supply depended almost entirely on the dynamics of one or two lakes. Discharge in these areas ranged from near zero to $>20 \mathrm{~m}^{3} \mathrm{~s}^{-1}$ per $25 \mathrm{~km}^{2}$ gridcell. In other areas, such as upstream of Mac1, the presence of multiple nearby lakes maintained a more consistent water supply. Upstream lakes such as Mac7 appear to have strongly influenced the water available for the tributary region downstream (Fig. 7).

\subsection{Winberry lakes}

In all model runs, the lakes of Winberry and others (2009) received only a small amount of water, roughly $0.13-$ $0.19 \mathrm{~m}^{3} \mathrm{~s}^{-1}$. If flooding were to have occurred for just $10 \mathrm{~min}$ every 2 weeks (as observed by the seismic array) with no interim leakage, then the average discharge rate during the flood would have been $\sim 300 \mathrm{~m}^{3} \mathrm{~s}^{-1}$. Applying the Walder and Fowler (1994) model to this channel, as described by Carter and others (2009b), we find that the channel would need to be substantially larger than inferred by Winberry and others (2009) to carry this flow. If, however, the discharge was $\sim 100 \mathrm{~m}^{3} \mathrm{~s}^{-1}$ with large sediment $(\sim 1 \mathrm{~mm})$, then a channel $80 \mathrm{~m}$ wide and $70 \mathrm{~cm}$ deep could have delivered the required flow and fall within the range of seismically inferred channel geometries. Given the DEM sampling errors relative to the small catchment feeding these lakes and the short event duration ( 2 weeks) relative to ICESat temporal sampling (3-4 months), it is promising that the channel dimensions predicted by our model were within an order of magnitude of those inferred through seismic analysis (Fig. 2e).

\subsection{Water budgets}

Observed volume changes can account for all the meltwater produced in the MaclS catchment. This agreement between modeled and observed lake volume changes was impressive, given the simplicity of our model. This result makes us optimistic that more sophisticated subglacial water models (in which parameters such as conduit geometry, hydrologic conductivity, sediment storage and water temperature evolve over time) will be able to simulate observed volume changes if sufficient data are available (e.g. ice surface and bedrock geometry, ice surface velocity and lake distribution). Below we explore the differences between modeled and observed volume changes and speculate on modeling and data improvements that could resolve these discrepancies.

\subsubsection{Mac3, Mac4 and Mac5}

Our model did not reproduce observed filling rates for either Mac4 or Mac5 $\left(2.1 \pm 0.4 \mathrm{~m}^{3} \mathrm{~s}^{-1}\right.$ and $5.3 \pm 1 \mathrm{~m}^{3} \mathrm{~s}^{-1}$, respectively) for any time interval. However, the combined modeled filling rate of the two lakes $\left(7.3 \mathrm{~m}^{3} \mathrm{~s}^{-1}\right)$ closely matched the combined observed rate for June-November 2005. The difference between modeled and observed volume change was $<0.05 \mathrm{~km}^{3}$, or $\sim 13 \%$ of the total volume change, which is comparable to the $\sim 20 \%$ error in the volume estimates. The difference between modeled and observed volume change was of the same magnitude as the volume change for Mac6 and Mac7 (Fig. 8a). Even when the filling of Mac3 is included in our water budget, we maintained good agreement between the modeled rate of $11.7 \mathrm{~m}^{3} \mathrm{~s}^{-1}$ and observed rates of total volume change during both the beginning and end of the observation period $\left(10.2 \pm 2 \mathrm{~m}^{3} \mathrm{~s}^{-1}\right.$ and $13 \pm 2.6 \mathrm{~m}^{3} \mathrm{~s}^{-1}$, respectively). We were unable, however, to account for all the water in the system during a Mac4 drainage event from November 2005 to March 2006. This disagreement is not surprising, given that the model assumed instantaneous downstream transport and did not account for other means of water storage. Changes in ice till porosity (Tulaczyk and others, 2000) and water layer thickness (Creyts and Schoof, 2009) could account for some of the missing water. Also, since our model did not have explicit lake drainage mechanisms, there may have been unaccounted interactions between Mac4 and Mac5; for example, Fricker and others (2010) showed evidence of flow back and forth between Mac4 and Mac5.

\subsubsection{Mac2}

The model produced a volume change for Mac2 of $0.33 \mathrm{~km}^{3}$ between November 2003 and November 2005, compared to an observed volume change of $0.3 \mathrm{~km}^{3}+20 \%$ (Fig. $7 \mathrm{~b}$ ). On shorter timescales, however, the modeled and observed volume changes differed by larger amounts. Observations showed that most water arrives between March 2005 and November 2005, whereas the model predicted steady filling for most of the longer period. We attribute this discrepancy to our assumption that water was stored only in known lakes. Given the sparse ICESat track spacing and the paucity of RES data upstream of Mac2, it is possible that there was a subglacial lake upstream which could have stored the unaccounted water. Increased till porosity or changes in the upstream mean water thickness could have provided additional storage upstream of Mac2. Modeling by Creyts and Schoof (2009) suggests that water sheets could undergo thickness changes of $\sim 0.1 \mathrm{~m}$ due to subtle regional pressure changes. Such changes occurring over a $50 \mathrm{~km} \times 50 \mathrm{~km}$ area upstream of Mac2 between March and November 2005 could have generated the observed volume increase, which would not have been detectable by ICESat repeat-track analysis or MODIS image differencing. Another possible source of discrepancy is that there was an unexpectedly large modeled volume increase caused by apparent leakage of water from the Mac3-Mac5 system between March and 

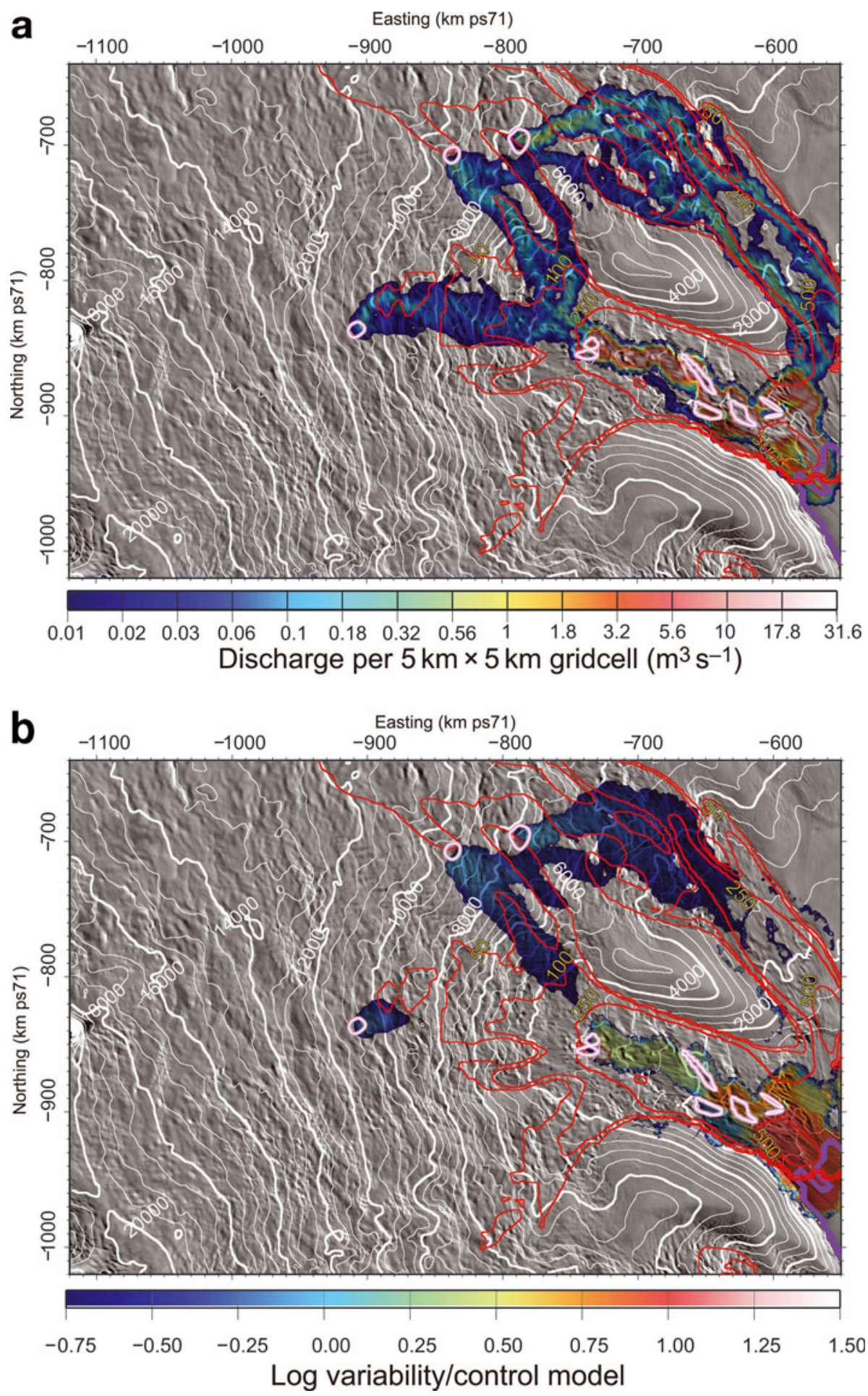

Fig. 7. (a) Range of discharge values from model (maximum-minimum). (b) Log ratio of flux variability to steady-state control flux.

June 2004. Although a distributed drainage system could potentially radiate into several different flow paths (Roberts, 2005), it is unclear if this was the case here.

\subsubsection{Mac1}

The modeled volume increase for Mac1 was $0.71 \mathrm{~km}^{3}$ from June 2005 to March 2008, which was consistent with the observed volume change of $0.69 \pm 0.14 \mathrm{~km}^{3}$ (Fig. 8b). We considered how the Mac1 water sources combine to account for the observed filling (Fig. 8c). More than half the water comes directly from Mac3, with an additional $21 \%$ from Mac2. We can attribute $20 \%$ of the volume change to water upstream of Mac2 and Mac3 passing through them as they drain. Only $8 \%$ of the volume change is attributed to basal melt associated with shear heating at a sticky spot immediately upstream. As with other lakes, there are timing differences of up to 4 months between modeled and observed volume changes. We may also be observing an artifact of estimating volume changes by averaging repeats of all ICESat tracks across the lake during a 33 day campaign to represent the lake state in the middle of that campaign. All three ICESat tracks across Mac1 show monotonically increasing surface elevation. In particular, the track farthest downstream (track 355) shows at least $0.5 \mathrm{~m}$ of surface rise 
a

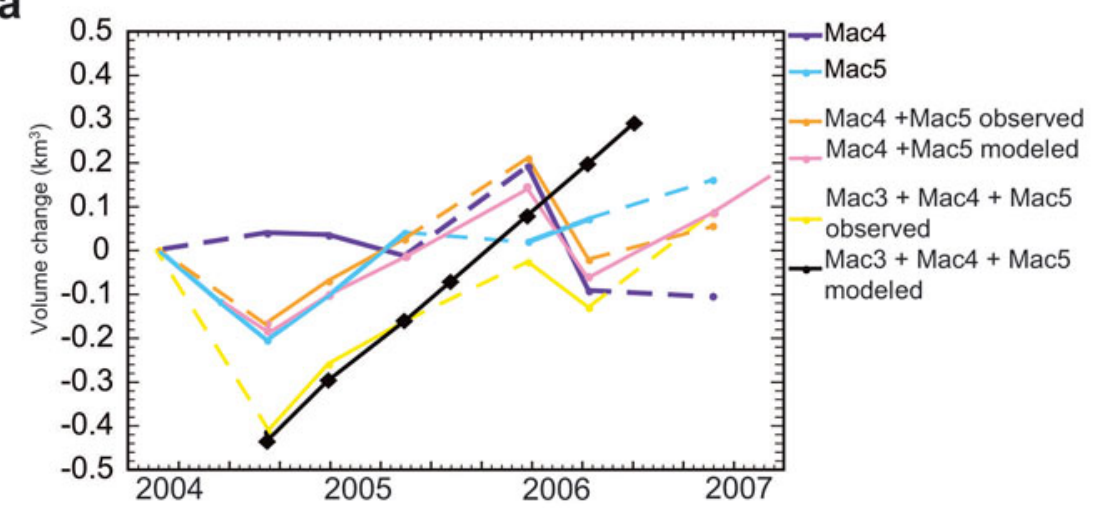

b

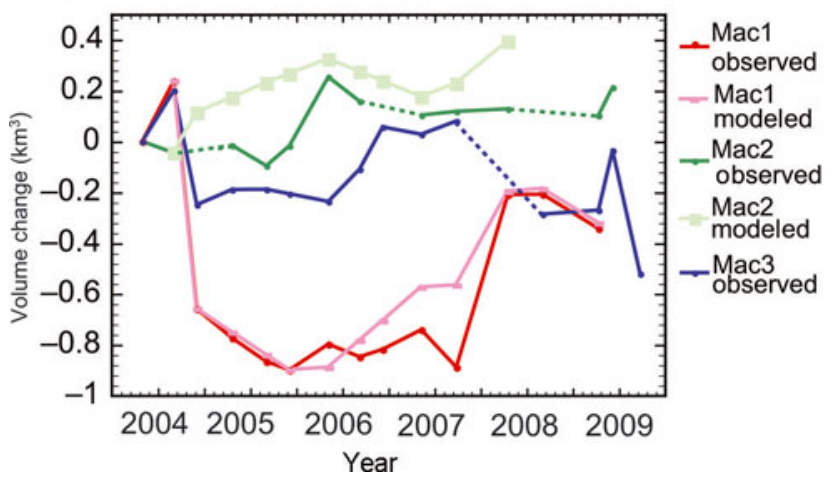

C

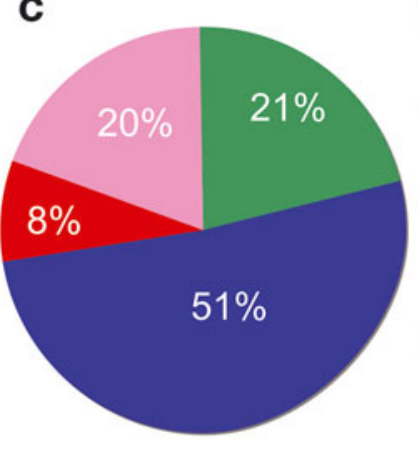

Mac3:

Mar 07- Oct 07

Mac2:

Nov 05-Nov 06

Melt from shear

heating at

nearby sticky

spot

Melt passing

through other

lakes as they

flood

Fig. 8. (a, b) Modeled and observed water budgets for (a) Mac3-Mac5 and (b) Mac1-Mac3. (c) Pie chart showing provenance of water that fills Mac1 between June 2005 and November 2007. Resolution of the Mac4 and Mac5 water budget is more effective if both lakes are treated as parts of a single combined lake.

(Fricker and others, 2010). The downstream portion of the lake may maintain a constant pool of water, while water depths in the upper parts of the lake are more variable. We found that Mac1 volume fluctuations depended on the dynamics of upstream lakes; much of the water that passed through this lake originated far upstream.

\section{DISCUSSION}

\subsection{Open or closed system?}

The combined water budget for Mac3-Mac5 shows a nearly linear monotonic increase in total water storage between June 2004 (at the end of the Mac3 flood) and November 2006 (the start of the next flood). This suggests that a majority of the upstream water passes through these three lakes, with little leakage. There is some indication, however, that the filling rate decreased with time. One explanation for this is that lakes upstream were storing water that would otherwise feed this system, although we expect this amount to be small. Smith and others (2009) reported that Mac7 (labeled 'Bindschadler $5^{\prime}$ in that study) received $\sim 0.03 \mathrm{~km}^{3} \mathrm{a}^{-1}$ between October 2003 and October 2007, an amount equivalent to the reduced filling of the Mac3-Mac5 system. Mac6 lost $0.05 \mathrm{~km}^{3}$ during the same period (Smith and others, 2009). If the majority of the loss from Mac6 occurred between June 2004 and November 2006, then the filling rates for Mac3Mac5 would have been higher than modeled rates.

\subsection{Local versus regional sourcing}

There is some debate as to whether subglacial lakes obtain water from local or distant sources (Bell and others, 2007;
Bindschadler and Choi, 2007; Fricker and Scambos, 2009). Subglacial lakes near ice divides exist, in part, as a result of high geothermal flux and the presence of hydrologic potential basins (Siegert, 2000; Tikku and others, 2005; Bell, 2008; Carter and others, 2009b). For ice-stream regions, however, the lakes could not have behaved as observed without receiving water from the wider catchment. Of the five MaclS lakes farthest downstream (Mac1-Mac5), only Mac5 appears to have been filled by constant hydrologic flux. The other lakes, even those with no known lakes upstream, appear to have filling rates that were influenced by the episodic storage and release of water from upstream lakes. As the flooding of these lakes depends in part on their filling rate (Evatt and others, 2006), the water distribution downstream will be the sum of many interrelated events and will be nonlinear over time. Several modelers have tried to link lake formation with high melt rates at sticky spots (Stokes and others, 2007; Sergienko and Hulbe, 2011). This study does not refute that enhanced frictional melting may play a role in lake formation beneath fast-moving ice masses, but it does suggest that observed lake behavior in fast-flowing areas cannot be explained by local melt sources alone. Indeed, if the nearest sticky spot were the sole source of meltwater for Mac1, the resulting surface elevation change would have been $<1 \mathrm{~m}$ over the ICESat period and might not have been identified. It is possible that the traction contrast across sticky spots creates many small lakes that are not detectable with ICESat. The lakes in the inventory of Smith and others (2009) may have been only a subsample of lakes that were either draining at the time or were fed by a large hydrologic catchment basin. 
The volume change for the downstream lakes shows a clear link to upstream lakes and to meltwater produced throughout the basin. We can thus confirm with observations what models have shown (Parizek and others, 2002; Le Brocq and others, 2009): that subglacial water in fastflowing areas is transported from areas of net basal melting to areas of net accretion.

\subsection{Subglacial lake floods dominate the water budget in fast-flow regions}

A map of ice velocity and discharge variability for the MaclS drainage basin shows that $>55 \%$ of ice moving at $250 \mathrm{~m} \mathrm{a}^{-1}$ or faster is underlain by a highly variable subglacial water system (Fig. 7). Given that Bindschadler, Whillans and Mercer ice streams also have several active subglacial lakes, as do most fast-flowing outlet glaciers in Antarctica (Fricker and others, 2007; Smith and others, 2009), we can assume that subglacial floods influence the basal water distribution in these other regions. Much research has explored the links between water distribution and basal sliding for ice sheets (e.g. Weertman, 1972; Fowler 1986; Iken and Bindschadler, 1986; Alley, 1989; Tulaczyk and others, 2000; Arnold and Sharp, 2002; Johnson and Fastook 2002; Le Brocq and others, 2009; Schoof 2010; Pimentel and Flowers, 2011). This work has showed that, for basal water in distributed systems where effective pressure decreases with increasing discharge, higher discharges will lead to increased sliding, through softening of the subglacial till or increased separation between the ice and the bed. In contrast, subglacial conduits in which effective pressure increases with discharge will tend to enhance basal traction by efficiently removing basal water from subglacial cavities and till. The subglacial water models that have dealt exclusively with Antarctica and the Siple Coast (Johnson and Fastook, 2002; Le Brocq and others 2009) have assumed a distributed system in quasi-steady state. This assumption was justified in part because in the Siple Coast ice streams, low ice surface gradients $(\sim 0.1 \%)$ limit the energy available to melt conduit walls, and large ice thicknesses $(\sim 1000 \mathrm{~m})$ create high basal pressures that would close channels rapidly (Alley 1989, 1996). However, recent studies on the evolution of subglacial floods in Antarctica (Evatt and others, 2006; Evatt and Fowler, 2007; Carter and others, 2009a; Fowler 2009) have shown that subglacial conduits are a plausible flow mechanism. Although our study does not deal directly with flow mechanisms, it does show that flooding events can account for nearly all the water produced in a subglacial catchment. It also highlights the importance of further study of the mechanisms of flood initiation and water transport, in order to accurately represent the relationship between the subglacial water system and the flow of overlying ice.

\subsection{Higher-resolution validation and tuning of basal water models}

Incorporating subglacial lake volume changes for model runs covering the ICESat period may not require the full physics of subglacial floods, but could be done with the simple parameterization described here. Such a model, however, would apply only to the period of the ICESat campaigns (2003-09), and volume changes would need to be well constrained and independently verified by other data (e.g. GPS, ice surface velocity, RES reflections and MODIS image differencing (e.g. Fricker and others, 2010)). Furthermore, our method is sensitive to ice surface and bedrock geometry, and therefore requires relatively dense and accurate surface and ice thickness measurements. Unfortunately, data of sufficient quality are currently not available for most of Antarctica.

Evolutionary ice-sheet water models will need to simulate lake formation, filling and drainage in a way that is independent of data on their current distribution. Work by Sergienko and Hulbe (2011) shows promise for demonstrating how traction contrasts associated with sticky spots result in local minima in the ice surface, creating enclosed basins in the hydrologic potential downstream. As water collects, it enhances basal lubrication, increasing the traction contrast in a positive feedback. Whereas the models of Johnson and Fastook (2002) and Le Brocq and others (2009) manually filled in the local minima in the hydrologic potential, it may be more realistic to have such minima fill, drain and overflow as the ice sheet evolves. We would begin by applying the model described in this study to domain that includes only MaclS and other areas where the data are sufficient for 2003-09 and then expand it to the larger icesheet system for longer runs with an evolutionary lake model (e.g. Sergienko and Hulbe, 2011).

The 2003-09 ICESat dataset for MacIS could be useful in developing and testing improved models of subglacial water evolution and lake volume change. When averaged over a period of several years, the modeled filling rates of Mac2Mac5 were consistent with observations. Higher-order water flow models, which include terms for changes in hydrologic conductivity, dynamic flow system geometry, water storage in subglacial tills, water-pressure evolution and/or water temperature (e.g. Flowers and Clarke, 2002; Evatt and others, 2006; Creyts and others, 2009; Schoof, 2010), could be applied and tested on the MaclS domain, at least along the flow paths identified here. To date, none of these models has been tested on an actual Antarctic subglacial flood. Also, our analysis of the Winberry and others (2009) flood shows promise for using seismic data to monitor small-scale and short-duration events that may not be detectable with ICESat data. Although no single class of observations or model can explain all subglacial water events in Antarctica, there exist adequate data in many regions to test key elements of models.

Finally, now that we have validated the hypothesis that lakes temporarily impound almost all the water that passes through them, we can resolve a catchment-wide water budget on the scale of individual lakes. Using this principle, we can infer hydrologic connections and bed topography where ice thickness data are sparse, such as at Recovery Glacier (Bell and others, 2007), if the behavior of nearby lakes is correlated. Although RES data are dense in the fastflowing regions of the Siple Coast, large areas farther upstream remain poorly surveyed. If the modeled behavior of subglacial lakes in the downstream areas is consistent with observations, then we can be more confident about the DEM and basal water distribution upstream.

\section{CONCLUSIONS}

Using a simple steady-state water model, with a published dataset for basal melt rates and adapted DEMs of ice surface and bedrock topography, we have reproduced subglacial lake volume changes estimated from satellite data analysis by Fricker and others (2010) for individual subglacial lakes in MaclS. For this system, we have validated the hypothesis 
that subglacial lakes temporarily impound nearly all water that passes through them. Our work provides solid evidence that downstream regions receive the majority of their water from the upper part of the catchment. Furthermore, the subglacial water budget for MaclS is approximately in balance over time.

We have also presented a reproducible means of parameterizing important sub-DEM-scale features in the ice surface and bedrock topography using the original RES line data. By demonstrating that the flow paths determined by this method are monotonically decreasing except where they intersect subglacial lakes, we have given observational justification to a long-practiced but rarely justified technique in which isolated depressions in the hydrologic potential are assumed to be filled.

Our modeling results lay the groundwork for using real data to validate such higher-order water flow models under development (e.g. Creyts and Schoof, 2009). Incorporating subglacial lake volume changes for model runs covering the ICESat period may not require the full physics of subglacial floods, but could be done with the simple parameterization described here. While most current ice-sheet models do not include models for subglacial water transport, this transport has long been invoked to explain observed ice behavior, especially for maintaining basal lubrication in the downstream regions of the Siple Coast ice streams where basal accretion is believed to occur (Joughin and others, 2004).

\section{ACKNOWLEDGEMENTS}

ICESat data analysis was funded through NASA Award NNX07AL18G. RES data collection was funded by NASA grant NNX08AN68G. The University of Texas Institute for Geophysics Support Office for Aerogeophysical Research through which many of the RES data in this paper were collected was supported by US National Science Foundation grant OPP-9120464, OPP-9319369. Funding during the analysis and writing was provided by the Scripps Institution of Oceanography Postdoctoral Program and the Institute of Geophysics and Planetary Physics of Los Alamos National Laboratory LLC subcontract No. 73593-001-09. The manuscript was improved by comments from and conversations with H. Pritchard, R. Bindschadler, T. Creyts, J. MacGregor, T. Haran, T. Scambos, C. Jackson and A. Le Brocq.

\section{REFERENCES}

Alley, R.B. 1989. Water-pressure coupling of sliding and bed deformation: I. Water system. J. Glaciol., 35(119), 108-118.

Alley, R.B. 1996. Towards a hydrological model for computerized ice-sheet simulations. Hydrol. Process., 10(4), 649-660.

Anandakrishnan, S. and R.B. Alley. 1997. Stagnation of Ice Stream C, West Antarctica by water piracy. Geophys. Res. Lett., 24(3), 265-268.

Arnold, N. and M. Sharp. 2002. Flow variability in the Scandinavian ice sheet: modelling the coupling between ice sheet flow and hydrology. Quat. Sci. Rev., 21(4-6), 485-502.

Bell, R.E. 2008. The role of subglacial water in ice-sheet mass balance. Nature Geosci., 1(5), 297-304.

Bell, R.E., M. Studinger, C.A. Shuman, M.A. Fahnestock and I. Joughin. 2007. Large subglacial lakes in East Antarctica at the onset of fast-flowing ice streams. Nature, 445(7130), 904-907.

Bentley, C.R. and F.K. Chang. 1971. Geophysical exploration in Marie Byrd Land, Antarctica. In Crary, A.P., ed. Antarctic snow and ice studies II. Washington, DC, American Geophysical Union, 1-38. (Antarctic Research Series 16.)

Bentley, C.R. and N.A. Ostenso. 1961. Glacial and subglacial topography of West Antarctica. J. Glaciol., 3(29), 882-911.

Bindschadler, R. and H. Choi. 2007. Increased water storage at ice-stream onsets: a critical mechanism? J. Glaciol., 53(181), 163-171.

Blankenship, D.D., R.E. Bell, S.M. Hodge, J.M. Brozena, J.C. Behrendt and C.A. Finn. 1993. Active volcanism beneath the West Antarctic ice sheet and implications for ice-sheet stability. Nature, 361(6412), 526-529.

Blankenship, D.D. and 9 others. 2001.Geologic controls on the initiation of rapid basal motion for West Antarctic ice streams: a geophysical perspective involving new airborne radar sounding and laser altimetry results. In Alley, R.B. and R.A. Bindschadler, eds. The West Antarctic ice sheet: behavior and environment. Washington, DC, American Geophysical Union, 105-121. (Antarctic Research Series 77.)

Carter, S.P., D.D. Blankenship, M.E. Peters, D.A. Young, J.W. Holt and D.L. Morse. 2007. Radar-based subglacial lake classification in Antarctica. Geochem, Geophys., Geosyst., 8(3), Q03016. (10.1029/2006GC001408.)

Carter, S.P., D.D. Blankenship, D.A. Young and J.W. Holt. 2009a. Using radar-sounding data to identify the distribution and sources of subglacial water: application to Dome C, East Antarctica. J. Glaciol., 55(194), 1025-1040.

Carter, S.P., D.D. Blankenship, D.A. Young, M.E. Peters, J.W. Holt and M.J. Siegert. 2009b. Dynamic distributed drainage implied by the flow evolution of the 1996-1998 Adventure Trench subglacial outburst flood. Earth Planet. Sci. Lett., 283(1-4), 24-37.

Creyts, T.T. and G.K.C. Clarke. 2010. Hydraulics of subglacial supercooling: theory and simulations for clear water flows. J. Geophys. Res., 115(F3), F03021. (10.1029/2009JF001417.)

Creyts, T.T. and C.G. Schoof. 2009. Drainage through subglacial water sheets. J. Geophys. Res., 114(F4), F04008. (10.1029/ 2008JF001215.)

Drewry, D.J. 1975. Radio echo sounding map of Antarctica $\left(\sim 90^{\circ} \mathrm{E}-180^{\circ}\right)$. Polar Rec., 17(109), 359-374.

Dupain-Triel, J.L. 1791. La France considérée dans les différentes hauteurs de ses plaines: ouvrage spécialement destiné à l'instruction de la jeunesse. Paris, Hérault.

Engelhardt, H. and B. Kamb. 1997. Basal hydraulic system of a West Antarctic ice stream: constraints from borehole observations. J. Glaciol., 43(144), 207-230.

Evatt, G.W. and A.C. Fowler. 2007. Cauldron subsidence and subglacial floods. Ann. Glaciol., 45, 163-168.

Evatt, G.W., A.C. Fowler, C.D. Clark and N.R.J. Hulton. 2006. Subglacial floods beneath ice sheets. Philos. Trans. R. Soc. London, Ser. A, 364(1844), 1769-1794.

Flowers, G.E. and G.K.C. Clarke. 2002. A multicomponent coupled model of glacier hydrology: 1 . Theory and synthetic examples. J. Geophys. Res., 107(B11), 2287. (10.1029/2001JB001122.)

Fowler, A.C. 1986. Sub-temperate basal sliding. J. Glaciol., 32(110), 3-5.

Fowler, A.C. 2009. Dynamics of subglacial floods. Proc. R. Soc. London, Ser. A, 465(2106), 1809-1828.

Fricker, H.A. and T. Scambos. 2009. Connected subglacial lake activity on lower Mercer and Whillans Ice Streams, West Antarctica, 2003-2008. J. Glaciol., 55(190), 303-315.

Fricker, H.A., T. Scambos, R. Bindschadler and L. Padman. 2007. An active subglacial water system in West Antarctica mapped from space. Science, 315(5818), 1544-1548.

Fricker, H.A., T. Scambos, S. Carter, C. Davis, T. Haran and I. Joughin. 2010. Synthesizing multiple remote-sensing techniques for subglacial hydrologic mapping: application to a lake system beneath MacAyeal Ice Stream, West Antarctica. J. Glaciol., 56(196), 187-199.

Gray, L., I. Joughin, S. Tulaczyk, V.B. Spikes, R. Bindschadler and K. Jezek. 2005. Evidence for subglacial water transport in the 
West Antarctic Ice Sheet through three-dimensional satellite radar interferometry. Geophys. Res. Lett., 32(3), L03501. (10.1029/2004GL021387.)

Haran, T.M. and T.A. Scambos. 2007. Enhancing a RADARSAT/ ICESat digital elevation model of West Antarctica using MODIS imagery. [Abstr. C51B-0386.] Eos, 88(52), Fall Meet. Suppl.

Holt, J.W., D.D. Blankenship, D.L. Morse, D.A. Young, M.E. Peters, S.D. Kempf, T.G. Richter, D.G. Vaughan and H.F.J. Corr. 2006. New boundary conditions for the West Antarctic Ice Sheet: subglacial topography of the Thwaites and Smith glacier catchments. Geophys. Res. Lett., 33(9) (10.1029/ 2005gl025561).

Iken, A. and R.A. Bindschadler. 1986. Combined measurements of subglacial water pressure and surface velocity of Findelengletscher, Switzerland: conclusions about drainage system and sliding mechanism. J. Glaciol., 32(110), 101-119.

Johnson, J. and J. Fastook. 2002. Northern Hemisphere glaciation and its sensitivity to basal melt water. Quat. Int., 95-6, 65-74.

Joughin, I., S. Tulaczyk, R.A. Bindschadler and S. Price. 2002. Changes in West Antarctic ice stream velocities: observation and analysis. J. Geophys. Res., 107(B11), 2289. (10.1029/ 2001JB001029.)

Joughin, I., S. Tulaczyk, D. MacAyeal and H. Engelhardt. 2004. Melting and freezing beneath the Ross ice streams, Antarctica. J. Glaciol., 50(168), 96-108.

Kamb, B. 1987. Glacier surge mechanism based on linked cavity configuration of the basal water conduit system. J. Geophys. Res., 92(B9), 9083-9100.

Le Brocq, A.M., A.J. Payne and M.J. Siegert. 2006. West Antarctic balance calculations: impact of flux-routing algorithm, smoothing algorithm and topography. Comput. Geosci., 32(10), 17801795.

Le Brocq, A.M., A.J. Payne, M.J. Siegert and R.B. Alley. 2009. A subglacial water-flow model for West Antarctica. J. Glaciol., 55(193), 879-888.

Llubes, M., C. Lanseau and F. Rémy. 2006. Relations between basal condition, subglacial hydrological networks and geothermal flux in Antarctica. Earth Planet. Sci. Lett., 241(3-4), 655-662.

Lythe, M.B., D.G. Vaughan and BEDMAP consortium. 2001. BEDMAP: a new ice thickness and subglacial topographic model of Antarctica. J. Geophys. Res., 106(B6), 11,335-11,351.

MacAyeal, D.R., R.A. Bindschadler and T.A. Scambos. 1995. Basal friction of Ice Stream E, West Antarctica. J. Glaciol., 41(138), 247-262.

Parizek, B.R., R.B. Alley, S. Anandakrishnan and H. Conway. 2002. Sub-catchment melt and long-term stability of Ice Stream D, West Antarctica. Geophys. Res. Lett., 29(8), 551-554.

Pimentel, S. and G.E. Flowers. 2011. A numerical study of hydrologically driven glacier dynamics and subglacial flooding. Proc. R. Soc. London, Ser. A, 467(2126), 537-558.

Pritchard, H.D., R.J. Arthern, D.G. Vaughan and L.A. Edwards. 2009. Extensive dynamic thinning on the margins of the Greenland and Antarctic ice sheets. Nature, 461(7266), 971-975.

Quinn, P.F., B. Ostendorf, K. Beven and J. Tenhunen. 1998. Spatial and temporal predictions of soil moisture patterns and evaporative losses using TOPMODEL and the GASFLUX model for an Alaskan catchment. Hydrol. Earth Syst. Sci., 2(1), 51-64.

Rignot, E. and 6 others. 2008. Recent Antarctic ice mass loss from radar interferometry and regional climate modelling. Nature Geosci., 1(2), 106-110.

Roberts, M.J. 2005. Jökulhlaups: a reassessment of floodwater flow through glaciers. Rev. Geophys., 43(1), RG1002. (10.1029/ 2003RG000147.)

Saunders, W. 2000. Preparation of DEMs for use in environmental modeling analysis. In Maidment, D. and D. Djokic, eds.
Hydrologic and hydraulic modeling support with geographic information systems. Redlands, CA, Environmental Systems Research Institute.

Schoof, C. 2010. Ice-sheet acceleration driven by melt supply variability. Nature, 468(7325), 803-806.

Sergienko, O.V. and C.L. Hulbe. 2011. 'Sticky spots' and subglacial lakes under ice streams of the Siple Coast, Antarctica. Ann. Glaciol., 52(58), 18-22.

Sergienko, O.V., D.R. MacAyeal and R.A. Bindschadler. 2007. Causes of sudden, short-term changes in ice-stream surface elevation. Geophys. Res. Lett., 34(22), L22503. (10.1029/ 2007GL031775.)

Shreve, R.L. 1972. Movement of water in glaciers. J. Glaciol., 11(62), 205-214.

Siegert, M.J. 2000. Antarctic subglacial lakes. Earth-Sci. Rev., $\mathbf{5 0}(1-2), 29-50$

Siegert, M.J., S. Carter, I. Tabacco, S. Popov and D.D. Blankenship. 2005. A revised inventory of Antarctic subglacial lakes. Antarct. Sci., 17(3), 453-460.

Siegert, M.J., A. Le Brocq and A.J. Payne. 2007. Hydrological connections between Antarctic subglacial lakes, the flow of water beneath the East Antarctic Ice Sheet and implications of sedimentary processes. In Hambrey, M.J., P. Christoffersen, N.F. Glasser and B. Hubbard, eds. Glacial sedimentary processes and products. Malden, MA, Blackwell Publishing, 3-10. (International Association of Sedimentologists Special Publication 39.)

Smith, B.E., H.A. Fricker, I.R. Joughin and S. Tulaczyk. 2009. An inventory of active subglacial lakes in Antarctica detected by ICESat (2003-2008). J. Glaciol., 55(192), 573-595.

Stearns, L.A., B.E. Smith and G.S. Hamilton. 2008. Increased flow speed on a large East Antarctic outlet glacier caused by subglacial floods. Nature Geosci., 1(12), 827-831.

Stokes, C.R., C.D. Clark, O.B. Lian and S. Tulaczyk. 2007. Ice stream sticky spots: a review of their identification and influence beneath contemporary and palaeo-ice streams. Earth-Sci. Rev., 81(3-4), 217-249.

Tikku, A.A., R.E. Bell, M. Studinger, G.K.C. Clarke, I. Tabacco and F. Ferraccioli. 2005. Influx of meltwater to subglacial Lake Concordia, East Antarctica. J. Glaciol., 51(172), 96-104.

Tulaczyk, S.M., B. Kamb and H.F. Engelhardt. 2000. Basal mechanics of Ice Stream B, West Antarctica. II. Undrainedplastic-bed model. J. Geophys. Res., 105(B1), 483-494.

Vogel, S.W. and S. Tulaczyk. 2006. Ice-dynamical constraints on the existence and impact of subglacial volcanism on West Antarctic ice sheet stability. Geophys. Res. Lett., 33(23), L23502. (10.1029/2006GL027345.)

Walder, J.S. and A. Fowler. 1994. Channelized subglacial drainage over a deformable bed. J. Glaciol., 40(134), 3-15.

Weertman, J. 1972. General theory of water flow at the base of a glacier or ice sheet. Rev. Geophys. Space Phys., 10(1), 287-333.

Winberry, J.P., S. Anandakrishnan, R.B. Alley, R.A. Bindschadler and M.A. King. 2009. Basal mechanics of ice streams: insights from the stick-slip motion of Whillans Ice Stream, West Antarctica. J. Geophys. Res., 114(F1), F01016. (10.1029/ 2008JF001035.)

Wingham, D.J., A. Shepherd, A. Muir and G.J. Marshall. 2006a. Mass balance of the Antarctic ice sheet. Philos. Trans. R. Soc. London, Ser. A, 364(1844), 1627-1635.

Wingham, D.J., M.J. Siegert, A. Shepherd and A.S. Muir. $2006 \mathrm{~b}$. Rapid discharge connects Antarctic subglacial lakes. Nature, 440(7087), 1033-1036.

Wright, A.P., M.J. Siegert, A.M. Le Brocq and D.B. Gore. 2008. High sensitivity of subglacial hydrological pathways in Antarctica to small ice-sheet changes. Geophys. Res. Lett., 35(17), L17504. (10.1029/2008GL034937.) 